
68-84.

\title{
A playbill: Rethinking assessment in teacher education
}

\author{
Gina M. Borgioli ${ }^{1}$, Anne Ociepka², and Kristie Coker ${ }^{3}$
}

\begin{abstract}
In this article, we tell the story of inquiring about, designing, implementing and studying our enactment of non-traditional assessment practices in our elementary education university methods course. We organized this article using a theater playbill metaphor, starting with a prologue, followed by three acts and an intermission, and concluding with an epilogue. Our goal was to better align our assessment practices with our beliefs and values about teaching and learning. We discuss how reforming our assessment practices affected issues of equity for our pre-service teachers, such as their participation, identity, power, and agency in our classes. We hope to inspire readers to reflect on how their assessment practices affect students' learning and sense of agency.
\end{abstract}

Key Words: assessment; teacher education; equity

\section{The Back Story}

In this article, we tell the story of inquiring about, designing, implementing and studying our enactment of non-traditional assessment practices in our elementary education university methods course. We organized this article using a theater playbill metaphor, starting with a prologue, followed by three acts and an intermission, and concluding with an epilogue. The first two authors were instructors for the methods courses discussed in the play and the third author was a graduate student who assisted with the literature review and the writing. In the play that follows, we tell the story of our journey toward better aligning our assessment practices with our beliefs and values about teaching and learning. First, we describe the conversation that sparked our journey. Next, in three acts, we describe how our review of the literature prompted specific revisions to our assessment practices and our two-year qualitative research study of how those revisions affected the pre-service teachers in our classes. In the epilogue, we challenge ${ }^{1}$ readers to examine their own assessment practices, especially as experienced by their students. Ultimately, we also hope to invite a larger, more systemic conversation about the role that non-traditional assessment practices in teacher education programs might have on "moving educator preparation to excellence through continuous improvement and research-based

\footnotetext{
${ }^{1}$ Indiana University Purdue University at Indianapolis

${ }^{2}$ Indiana University Purdue University at Indianapolis

3Indiana University, Bloomington
} 
transformation" (Retrieved from the Council for the Accreditation of Educator Preparation (CAEP) on September 17, 2013 from http://www.caepsite.org/standards.html).

[curtain rises and Instructors speak]

\section{The Prologue}

Instructor 1: 'You know that 'What's in your wallet?' commercial? Well, lately I've been asking myself, 'What's in my syllabus?' especially related to assessment. I am feeling quite hypocritical, claiming to value the processes of pre-service teachers making meaning and taking ownership of their learning, yet having my assessment rely heavily on points, grades, and feedback on summative assessments. I feel that the current assessment system I am using serves mostly to label and externally reward the pre-service teachers.”

Instructor 2: "I agree! The tension I experience every semester is that I really commit to building community and getting to know the pre-service teachers. I stress to them how relationships with and among learners are crucial to authentic learning. But as soon as they get back their first graded assignment, there is a noticeable (often audible) shift in the relationship. For the rest of the semester, I struggle to keep their focus on the learning, rather than on their grades.”

Instructor 1: "I really would like to find a workable system of assessment that would truly support pre-service teachers' learning and self-efficacy. I'm wondering how we can modify our assessment practices so that they better align with our values. What would that look like?”

\section{ACT 1: What does the literature say about non-traditional assessment?}

After our initial conversation, we decided to devour research on non-traditional assessment. We began by reading Black, Harrison, Lee, Marshall, and Wiliam (2007), who reported findings on studies of three types of assessment in which teachers often engageproviding students with only grades, providing grades and written feedback, or providing only written feedback about their progress toward learning targets. In these studies, the latter group increased their academic achievement in the subject significantly, whereas those who received grades did not. And, those who received grades and feedback did as poorly as those who received only grades. The grade always appeared to override the feedback. Since giving points and grades with many comments was the dominant manner in which we, and most of our colleagues in our School of Education, assessed pre-service teachers' work, we were deeply troubled by these findings and intrigued to find out more. We began to think about how we might maximize the feedback offered to the pre-service teachers on course assignments and minimize the grade.

As we continued our review of the literature, it became clear that we wanted to pursue two key search terms: formative assessment and assessment for learning. We learned that formative assessment has been a hot topic in education. Both the national

Journal of the Scholarship of Teaching and Learning, Vol. 15, No. 3, June, 2015. josotl.indiana.edu 
councils in English language arts and mathematics education have recently issued formal Position Statements on the value of formative assessment. Three important ideas from these statements guided us as we reformed our assessment practices. First, assessment that is formative must be informative to teachers, students, and families (National Council of Teachers of English, 2013). Second, formative assessment has a positive impact on student motivation and it supports students in actively monitoring their own learning. Finally, formative assessment results in higher achievement (The National Council of Teachers of Mathematics, 2013). Additionally, Wiliam (2007, pp. 1-4) offered the following "five keys" to effective assessment for learning implementation that, as we will discuss later, provided a blue print for our journey in reforming our assessment practices.

1. Clarifying, sharing, and understanding goals for learning and criteria for success with learning;

2. Engineering effective classroom discussions, questions, activities, and tasks that elicit evidence of students' learning;

3. Providing feedback that moves learning forward;

4. Activating students as owners of their own learning; and

5. Activating students as learning resources for one another.

Stiggins (2002) helped us distinguish between assessment for learning and assessment of learning. He purported that both are necessary, but currently only the latter is in place and it dominates most assessment practice. However, when teachers assess for learning, they "use the classroom assessment process and the continuous flow of information about student achievement that it provides in order to advance, not merely check on, student learning” (p. 5). The process he offered teachers mirrors, in many ways, the five keys suggested by Wiliam (2007).

In 2012, an entire issue of Educational Leadership was focused on formative assessment. In that issue, Wiggins (2012) noted that effective feedback is "goal-referenced; tangible and transparent; actionable; user-friendly (specific and personalized); timely; ongoing; and consistent” (p. 13). Black and Wiliam (2004) referred back to Butler's (1987) work regarding the effects of feedback on students' motivation and self-esteem and cautioned against feedback given as grades.

Feedback given as rewards or grades enhances ego rather than task involvement; that is to say, it leads students to compare themselves with others and focus on their image and status rather than encouraging them to think about the work itself and how they can improve it (Black \& Wiliam, 2004, p. 30).

The above research was centered on applications of these concepts in the K-12 setting; however, we decided to think about how these concepts might play out in higher education. We found a thought-provoking article by McClam and Sevier (2010) about their upstream struggle to push against the status quo of assessment via points/grades in higher education. As doctoral students, these authors were teaching a methods course in a teacher education program that was steeped in theory about equity, social justice, and translational research and they were striving to enact that theory in their practice. 
Letter grades cannot capture the complexity of the learner or the learning process; grades actually serve to undermine students' intrinsic motivations to learn; grades are often/typically used to rigidly denote students as "successful" or "unsuccessful”; and ... grades effectively exclude students from determining for themselves the value of their classroom experience(s) and the direction(s) of their own learning (McClam \& Sevier, 2010, p. 1461).

They agreed with Kohn (1993) that striving for equity meant "bringing students into the evaluation process” (p. 209) in such a way that encourages the building of trust and relationships, attention to issues of identity, power, voice, and agency. They abandoned teacher-created grades and moved toward student self-assessment in an effort to "shift the balance of power in the classroom and model a democratic schooling experience" (McClam \& Sevier, 2010, p. 1461). Unfortunately, their story did not end well. The tenured and tenure-track professors in their department expressed disapproval about their nontraditional assessment practices and the Chair of the Department finally required them to return to a traditional system of points and grades. They wrote their article to discuss "the dramatic effects that [their] grading change produced for the students in the class, for the instructors in [the teacher education program], for the faculty at large within the School of Education, and for [themselves]” (p. 1461). They offered advice to others who would dare to journey down a similar path. That advice included: being transparent and communicating to others about the reform from the beginning; seeking feedback from other faculty members along the way; and involving students in the reform as much as possible. Their story resonated with us because we wanted to embark on that very same journey and we anticipated experiencing similar obstacles. Therefore, we took their advice to heart.

We consulted other studies of formative assessment that were situated in higher education. Nichol and Macfarlane-Dick (2006) found that feedback in higher education is "still largely controlled by and seen as the responsibility of teachers; and feedback is still generally conceptualized as a transmission process” (p. 200). Other researchers (Bose \& Rengel, 2009; Hattie \& Timperley, 2007) found that although higher education teachers are reluctant to give individual feedback due to its time-consuming nature, their students desire it because it allows them to identify areas of strength and areas of needed growth. Bose and Rengel (2009) claim that formative assessment in higher education is the key component in self-regulated learning. Others (Pintrich, 1995; Pintrich \& Zusho, 2002; Zimmerman \& Schunk, 2001, 2004) added that such learners are more persistent, resourceful, confident, less dependent and that "any student, even those 'at risk', can learn to become more self-regulating” (Pintrich \& Zusho, 2002, p. 205).

In an experimental quantitative study, McDowell, Wakelin, Montgomery and King (2011) employed the data from almost seven hundred questionnaires to explore the university students' experiences and determine the overall effectiveness of using assessment for learning (AfL) in university course modules. They defined an assessment for learning environment as one that: "is rich in formal feedback"; "is rich in informal feedback"; "provides opportunities to try out and practice knowledge, skills and understanding"; "has assessment tasks which are authentic or relevant"; "assists students to develop independence and autonomy"; and "has an appropriate balance between formative and summative assessments" (p. 750). Their findings indicated that "the overall 
student experience is more positive in modules where assessment for learning approaches are used and students are more likely to take a deep approach to learning” (p. 749).

\section{ACT 2: Reforming our assessment practice}

Informed by the literature, we moved to a plan of action. We set out to scrutinize and redesign our syllabi and our assessment practices. It was our intention to:

- build relations with and among our pre-service teachers that prioritized trust, collaboration, and ownership of their learning;

- design a classroom environment and course structures that would be more "support[ive] of the individual in the group context, [so that] students feel a part of a collective effort designed to encourage academic and cultural excellence” (Ladson-Billings, 2009, p. 82);

- develop a framework that supported us in enacting our beliefs and values about teaching and learning; and

- be sensitive to and to ultimately study how our pre-service teachers would experience these changes.

In order to accomplish these four goals, we made the following structural, instructional and assessment changes to our language and mathematics literacy methods courses. We started by applying the first of Wiliam's, (2007) five keys and developed a rubric with seven competencies (or learning targets) and developmental expectations for each competency [Table 1] in order to "clarify...the goals for learning and criteria for success with learning." (p. 1).

To address Wiliam's (2007) remaining four keys, we created space for structured group work by requiring some classwork and assignments be completed collaboratively in trios. We built in opportunities during class time for informal feedback (from instructors and from peers) on how the pre-service teachers' early drafts were progressing towards those seven competencies. Our intent was to provide specific feedback that assisted the preservice teachers in identifying areas of strength and areas of needed growth and to honor the process of creating and refining professional work products, both collaboratively and individually. On final products we required revisions on work that fell "below expectation" on any competency. In this way, our students would become an integral part of the assessment process (Kohn, 1993) and would receive an abundance of meaningful feedback in order to guide their learning process, rather than a single letter grade that labeled their learning product. We hoped that these cycles of feedback and revision would promote each pre-service teacher's awareness of his/her growth and learning over time. 


\section{Table 1}

Assessment Rubric: Directions: Pre-service teachers must demonstrate at least Level 2 competency in each criterion to pass the assignment. Best work is expected on the first submission. Revision is required for work below Level 2 in any competency. Except in rare circumstances, no more than one revision will be permitted.

\begin{tabular}{|c|c|c|c|}
\hline $\begin{array}{c}\text { Competency/ } \\
\text { Learning Target }\end{array}$ & $\begin{array}{c}\text { Level } 1 \text { / } \\
\text { Below Expectation }\end{array}$ & $\begin{array}{c}\text { Level } 2 \text { / } \\
\text { At Expectation }\end{array}$ & $\begin{array}{c}\text { Level } 3 / \\
\text { Exceeds Expectation }\end{array}$ \\
\hline $\begin{array}{l}\text { Disposition/ } \\
\text { Tone }\end{array}$ & $\begin{array}{l}\text { A strengths-based } \\
\text { disposition/tone is not } \\
\text { evident at all and/or the } \\
\text { task is not grounded in the } \\
\text { child's prior knowledge } \\
\text { or experiences }\end{array}$ & $\begin{array}{l}\text { A strengths-based } \\
\text { disposition/tone is evident } \\
\text { at times and/or the task is } \\
\text { not well grounded in the } \\
\text { child's prior knowledge } \\
\text { or experiences }\end{array}$ & $\begin{array}{l}\text { Disposition/tone is } \\
\text { strengths-based throughout } \\
\text { and/or the task is well } \\
\text { grounded in the child's } \\
\text { prior knowledge or } \\
\text { experiences }\end{array}$ \\
\hline $\begin{array}{l}\text { Connection to } \\
\text { Research }\end{array}$ & $\begin{array}{c}\text { Very few, if any, } \\
\text { connections to research } \\
\text { exist }\end{array}$ & $\begin{array}{l}\text { Connections to research } \\
\text { exist; most fit the context }\end{array}$ & $\begin{array}{l}\text { Many connections to } \\
\text { research exist; all fit the } \\
\text { context }\end{array}$ \\
\hline $\begin{array}{c}\text { Observation \& } \\
\text { Analysis }\end{array}$ & $\begin{array}{c}\text { Little } \\
\text { observation/evidence } \\
\text { exists }\end{array}$ & $\begin{array}{l}\text { Observation/evidence } \\
\text { exists; more description is } \\
\text { needed. Some analysis } \\
\text { exists (quantity); } \\
\text { however, more depth } \\
\text { (quality) is needed }\end{array}$ & $\begin{array}{c}\text { Descriptive } \\
\text { observation/evidence and } \\
\text { analysis exist. Analysis is } \\
\text { pervasive (quantity) } \\
\text { thorough and deep } \\
\text { (quality) } \\
\end{array}$ \\
\hline $\begin{array}{c}\text { Content } \\
\text { Knowledge }\end{array}$ & $\begin{array}{l}\text { Misconceptions with } \\
\text { content and/or vocabulary } \\
\text { exist or content } \\
\text { knowledge is not clearly } \\
\text { articulated }\end{array}$ & $\begin{array}{l}\text { No misconceptions with } \\
\text { content and/or vocabulary } \\
\text { exist; some areas need } \\
\text { more clarity and/or } \\
\text { precision }\end{array}$ & $\begin{array}{l}\text { Content knowledge is clear } \\
\text { and precise; complex } \\
\text { understanding is evident }\end{array}$ \\
\hline $\begin{array}{l}\text { Pedagogical } \\
\text { Knowledge }\end{array}$ & $\begin{array}{l}\text { Pedagogy is teacher- } \\
\text { directed and/or teacher- } \\
\text { centered and/or teaching } \\
\text { ideas are lacking and/or } \\
\text { are too vague to be } \\
\text { assessed }\end{array}$ & $\begin{array}{l}\text { Pedagogy is mostly child- } \\
\text { centered and inquiry- } \\
\text { based; some evidence of } \\
\text { listening and responding } \\
\text { to students' thinking } \\
\text { exists }\end{array}$ & $\begin{array}{l}\text { Pedagogy is child-centered } \\
\text { and inquiry-based; much } \\
\text { evidence of listening and } \\
\text { responding to students’ } \\
\text { thinking exists }\end{array}$ \\
\hline $\begin{array}{c}\text { Grammar/ } \\
\text { Writing/APA }\end{array}$ & $\begin{array}{l}\text { Many errors exist and } \\
\text { meaning is adversely } \\
\text { affected. Writing is not } \\
\text { well organized and/or } \\
\text { awkward word choice } \\
\text { and/or sentence structure } \\
\text { exists }\end{array}$ & $\begin{array}{l}\text { Some errors exist; } \\
\text { however, meaning is } \\
\text { maintained. Writing is } \\
\text { fairly well organized with } \\
\text { very few instances of } \\
\text { awkward word choice } \\
\text { and/or sentence structure }\end{array}$ & $\begin{array}{l}\text { Virtually free of errors. } \\
\text { Writing is well organized } \\
\text { with good flow; writer } \\
\text { 'voice' is present }\end{array}$ \\
\hline $\begin{array}{l}\text { Completeness/Evi } \\
\text { dence of Critical } \\
\text { Reflection \& } \\
\text { Collaboration }\end{array}$ & $\begin{array}{c}\text { Incomplete; little } \\
\text { evidence of critical } \\
\text { reflection; little evidence } \\
\text { of cooperation/ } \\
\text { collaboration exists (when } \\
\text { appropriate) }\end{array}$ & $\begin{array}{l}\text { Complete; evidence of } \\
\text { critical reflection; } \\
\text { evidence of cooperative } \\
\text { contributions toward a } \\
\text { common goal/product } \\
\text { exists (when appropriate) }\end{array}$ & $\begin{array}{l}\text { Complete; evidence of } \\
\text { critical reflection that } \\
\text { interrogates conventional } \\
\text { wisdom and practices; } \\
\text { evidence of collaborative } \\
\text { contributions toward a } \\
\text { common goal/ } \\
\text { product exists (when } \\
\text { appropriate) }\end{array}$ \\
\hline
\end{tabular}


Because our institution requires that a final grade be submitted to the Registrar for the pre-service teacher's transcript, we needed to find a way to translate each pre-service teacher's work and journey into a traditional grade of A, B, C, D or F. At the end of the semester, we decided we would meet with each pre-service teacher for fifteen to twenty minutes to accomplish the task of deciding on a final grade. We called these meetings exit conferences. During these exit conferences, the instructors and the pre-service teacher would review and discuss the pre-service teacher's work holistically and from multiple data points. Our goal was to determine a fair grade that would capture the essence of his/her work over the semester and that would be valid and reliable. Key data points that we thought we should collaboratively consider were: competency ratings for all assignments, including first submissions as well as revisions to enable noticing trends in the ratings as viewed chronologically over time; trends on how "best" or "revised" work compared to ratings on first submissions; attendance/punctuality; class participation-both in person and online; collaboration and engagement; and field work preparation. As we considered ratings, we did engage in some number crunching by calculating mean averages for each assignment submission and for each competency completed during the semester. Those mean averages assisted both the instructors and the pre-service teacher in making sense of and discussing the learning trends that emerged. The averages also helped when considering how the work and engagement of the pre-service teacher fared with regard to the following School of Education letter grade descriptors:

A Extraordinarily high achievement; shows unusually complete command of the subject matter; represents an exceptionally high degree of originality and creativity.

A- $\quad$ Exceptionally thorough knowledge of the subject matter; outstanding performance, showing strong analytical abilities.

$\mathrm{B}+\quad$ Significantly above average understanding of material and quality of work.

B Very good, solid, above average understanding of material and quality of work.

B- $\quad$ Good, acceptable performance.

C+ Satisfactory quality of work.

C Minimally acceptable quality of work.

C- to F Unacceptable work. Not meeting requirement for certification in the School of Education.

To better prepare the pre-service teachers for this collaborative process, we developed a learning activity that simulated an exit conference. This activity centered on a hypothetical student called Student X. Just after the midterm of the semester, we engaged small groups of pre-service teachers in analyzing Student X's course data, which included competency ratings from all assignments arranged in a spreadsheet along with notes about Student X's professionalism and engagement. The pre-service teachers were asked to look for trends in Student X's data and identify areas of strength and areas of needed growth. They were asked to use the letter grade descriptors in the syllabus to come to consensus on a letter grade that best captured what Student X had earned in the course. We found that consensus around a 'ball park grade' for Student $\mathrm{X}$ was not difficult to achieve. The groups easily agreed and could justify why Student X had earned a B or B- in the course. We felt that this simulation activity with Student X clarified the goal of the exit conference for both the pre-service teachers and for us. It was opportunity to engage in an honest and reflective 
conversation about the degree to which their course work and engagement demonstrated their competency in the learning targets and how we might collaboratively identify the letter grade that most accurately and fairly represented the work of the pre-service teacher throughout the semester. This process of designing and simulating an exit conference, we believed, supported us in building trust with the pre-service teachers and in paying closer attention to issues of their identity, power, voice, and agency in our methods class. We felt that we were joining with them in more of a coaching role, instead of towering above them in an authoritative, evaluative role. Now, we pause before we continue the story of how we listened to and studied the pre-service teachers' experiences with the assessment redesign.

\section{Intermission: A two-year time lapse}

We decided to call this section Intermission since there is a two-year break in our story. As described above, we redesigned our course towards assessment for learning in summer of 2010 and implemented the revised assessment framework with fifty-eight preservice teachers over the next two semesters (fall 2010 and spring 2011). In the following act we further describe the design of our research study, the analyses of the data, and the findings.

\section{ACT 3: Understanding Pre-service teachers' experiences}

As our journey continued, the question we wanted to study came into a clearer focus: What are the pre-service teachers' experiences with assessment for learning? We began collecting data, both informally and formally, from the pre-service teachers regarding their experiences.

As a regular part of our course, we paused to gather informal (and often, in the moment) data about how the pre-service teachers were feeling about our assessment for learning redesign. For example, we would often ask the pre-service teachers to either write or talk about what they liked and did not like about working in groups on some assignments and about not receiving traditional points and grades on their assignments. Immediately after they wrote or talked, we would explore their thoughts and feelings and we then brainstorm solutions together. For example, some pre-service teachers said they liked the group work and group assignments and some did not. When we discussed reasons why some did not like group work, we discovered that effort was often perceived as not being fairly distributed among members of the group. As instructors, we noted an opportunity and need to dive more deeply into supporting the interns in making sense of the rubric descriptors of “cooperation” (level 2) and “collaboration” (level 3). After hearing their thoughts and feelings, we agreed that we needed to provide them more time and support during class so they could learn how to do truly collaborative group work.

At the end of the course, we created an online survey to gather anonymous data on the pre-service teachers' experiences with assessment for learning. The two questions we asked were: (1) Which do you prefer and why? (grades, grades with written comments, or written comments on progress towards competencies only); and (2) In which of the seven competencies do you believe your instructors supported your growth? (disposition \& tone, connection to research, observation \& analysis of children's thinking, content knowledge,

Journal of the Scholarship of Teaching and Learning, Vol. 15, No. 3, June, 2015. josotl.indiana.edu 
inquiry-based pedagogy, scholarly writing, critical reflection \& collaboration). We also offered all of the pre-service teachers an opportunity to more formally participate in our action research study by meeting with us in small groups for interviews after the course was completed. Nine pre-service teachers decided to participate. During these interviews, we asked them to write and then talk with us about the following questions:

1. In this methods class, you completed some assignments in trios. Describe your thoughts and feelings/emotions (at beginning of semester, in middle of semester and at end of semester) about this idea.

2. In this methods class, you negotiated a final grade with the instructors without using a traditional point and percentage system. We looked holistically at your progress toward demonstrating certain competencies (disposition/tone, observation and analysis, connection to research, content knowledge, pedagogical knowledge, and writing). Describe your thoughts and feelings/emotions (at beginning of semester, in middle of semester and at end of semester) about this idea.

3. In this methods class, we studied and utilized 'assessment for learning' (as opposed to 'assessment of learning'). Describe your thoughts and feelings/emotions (at beginning of semester, in middle of semester and at end of semester) about this idea.

Twenty-nine of the fifty-eight pre-service teachers responded to the online survey and nine were willing to engage in interviews. The following served as data for our study:

- Interviews and journal entries from nine pre-service teachers about their thoughts at the beginning of the methods course

- Interviews and journal entries from nine pre-service teachers about their thoughts in the middle of the methods course

- Interviews and journal entries from nine pre-service teachers about their thoughts at the end of the methods course

- Online survey data from twenty-nine pre-service teachers

Most of our data was qualitative in nature, although some of the survey questions yielded a bit of quantitative data. Overall, we found that twenty-three of the twenty-nine pre-service teachers who responded to the survey preferred feedback only. Four preferred grades and feedback, and only 2 preferred only grades. Examples of the reasons expressed by those who indicated that they preferred feedback only were:

"I prefer this method because it helps me be more intrinsically motivated to learn and the rubric is broken into specific parts, making my strengths and weaknesses clear, rather than just receiving one overall percentage.” 
“...in a sense, this type of assessment allowed me to feel like a developing teacher among other professional teachers. My developing pedagogy was being guided, while at the same time being thoughtfully considered and responded to.”

From those that preferred grades or both grades and feedback:

"I would like [points/grades] on each assignments because employers are going to be looking at the grades we earned during our course work. I like to know exactly where I stand while going through the semester."

"I am torn between both of them because I like having a grade that I can refer to, but the feedback given on the rubrics is helpful.”

"I enjoy a combination of grades and feedback. I grew up receiving grades....so the transition to a rubric made me a little uneasy in the beginning...I enjoy knowing what my grades are before the last day of class.”

We also found that the areas in which the pre-service teachers felt that instructors most supported their growth were: content knowledge (86\%), inquiry-based pedagogy (90\%), connecting to research (90\%), and analysis of children's thinking (93\%).

We analyzed the interview and journal data using Strauss and Corbin's (1990) open coding technique. Each researcher separately identified key words and phrases from quotes from the pre-service teachers' written responses. From those key words and phrases, we identified a theme that captured their perceptions, sticking as closely to the pre-service teacher's own words as possible. We then compared the themes that emerged for each of us and came to a consensus on wording. For each quote, we then paired a theme with an emotion [Table 2]. As we interviewed each pre-service teacher, we asked him/her to identify emotions that he/she was feeling at the time. Whenever possible, we used the preservice teacher's exact descriptors for emotions. However, when the pre-service teacher did not offer a descriptor, we made conjectures about the emotions that were expressed. In this way, our analysis employs grounded theory because it is "anchored in the words, experiences, and meaning making of participants” (Jones, 2002, p. 176).

Identified themes included: focus on grades, having clear expectations, feedback from instructors, doing revisions, amount of work load, focus on learning, support of a learning community, new grading system, shifts in personal identity, shifts in beliefs and motivation, and personal as well as professional growth. Identified emotions included: apprehensiveness, worry, discomfort, insecurity, frustration, nervousness, happy, confidence, trust, pride, optimism, excitement, and curiosity. 
Borgioli, G. M., Ociepka, A., \& Coker, K.

Table 2

Sample Analyses of Journal Entries

\begin{tabular}{|c|c|c|}
\hline Quotes & Key Phrases & $\begin{array}{l}\text { Emotion/ } \\
\text { Theme }\end{array}$ \\
\hline $\begin{array}{l}\text { In the midst of listening to more } \\
\text { information, [Instructor A] says } \\
\text { something about how we will not be } \\
\text { receiving grades or points. Wait; did she } \\
\text { really just say no grades or even points? } \\
\text { How will I ever know how I'm doing? } \\
\text { How will I know what grade I will need } \\
\text { on each assignment to get the grade I } \\
\text { want? } \\
\text { Emotion identified: "Nervous and } \\
\text { apprehensive” }\end{array}$ & $\begin{array}{l}\text { How will I know how } \\
\text { I'm doing? } \\
\text { How will I know } \\
\text { what grade I will } \\
\text { need to get? }\end{array}$ & $\begin{array}{l}\text { Apprehensivel } \\
\text { Grade Focused }\end{array}$ \\
\hline $\begin{array}{l}\text { Honestly, the word revise made me } \\
\text { shudder. I was certain I would be } \\
\text { drowning in a mountain of revisions. } \\
\text { Emotion identified: “Apprehensive” }\end{array}$ & $\begin{array}{l}\text { Revising made me } \\
\text { shudder } \\
\text { Apprehensive about } \\
\text { drowning in a } \\
\text { mountain of revisions }\end{array}$ & $\begin{array}{l}\text { Apprehensive/ } \\
\text { Work Load }\end{array}$ \\
\hline $\begin{array}{l}\text { I had already printed off and marked up } \\
\text { the syllabus for reading and math, color- } \\
\text { coded and all. As a student, I like } \\
\text { organization and structure. I like to know } \\
\text { where I am in the class academically, and } \\
\text { I want to know up front exactly what is } \\
\text { expected of me. So, when we began to } \\
\text { discuss the syllabus, our professors went } \\
\text { over assignments and their expectations. } \\
\text { Everything was good! }\end{array}$ & $\begin{array}{l}\text { Expects organization } \\
\text { and structure } \\
\text { I like to know where } \\
\text { I am in the class } \\
\text { academically } \\
\text { I want to know up } \\
\text { front exactly what is } \\
\text { expected of me. }\end{array}$ & $\begin{array}{l}\text { Happy/ } \\
\text { Clear expectations }\end{array}$ \\
\hline Emotion identified: "Happy” & & \\
\hline
\end{tabular}

We chronologically (from beginning, middle, and end of semester) organized the most prominent themes by their associated emotions into a frequency table. We recorded the number of times a theme occurred during each data set time period (beginning, middle, and end of semester) and the different emotions that accompanied it. We ranked the themes according to the frequency of their occurrence in all of the pre-service teachers' journal writings (Table 3).

Journal of the Scholarship of Teaching and Learning, Vol. 15, No. 3, June, 2015. josotl.indiana.edu 
Borgioli, G. M., Ociepka, A., \& Coker, K.

Table 3

Beginning of Semester Frequency Table

\begin{tabular}{|c|c|c|c|}
\hline Themes & Emotions & \begin{tabular}{|l|} 
Tallies \\
\end{tabular} & $\begin{array}{l}\text { Frequency } \\
\text { (out of } 16 \text { total } \\
\text { data points in } \\
\text { 'Beginning' data } \\
\text { set) }\end{array}$ \\
\hline Grade Focused & Apprehensive & 3 & \\
\hline Grade Focused & Discomfort & 1 & \\
\hline Grade Focused & Insecure & 1 & \\
\hline Grade Focused & & & $5 / 16$ \\
\hline $\begin{array}{l}\text { Work } \\
\text { Load/Revisions }\end{array}$ & Optimism & 2 & \\
\hline $\begin{array}{l}\text { Work } \\
\text { Load/Revisions }\end{array}$ & Excitement & 1 & \\
\hline $\begin{array}{l}\text { Work } \\
\text { Load/Revisions }\end{array}$ & Apprehensive & 2 & \\
\hline $\begin{array}{l}\text { Work } \\
\text { Load/Revisions }\end{array}$ & & & $5 / 16$ \\
\hline $\begin{array}{l}\text { New Grading } \\
\text { System }\end{array}$ & Excited & 2 & \\
\hline $\begin{array}{l}\text { New Grading } \\
\text { System }\end{array}$ & Curious & 1 & \\
\hline $\begin{array}{l}\text { New Grading } \\
\text { System }\end{array}$ & & & $3 / 16$ \\
\hline Clear Expectations & Happy & 1 & $1 / 16$ \\
\hline Focus on Learning & Optimism & 1 & $1 / 16$ \\
\hline $\begin{array}{l}\text { Feedback from } \\
\text { Instructors }\end{array}$ & Optimism & 1 & $1 / 16$ \\
\hline Miscellaneous & & & $3 / 16$ \\
\hline
\end{tabular}

According to Jones (2002), this analytic process "can be understood as storytelling” (p. 176). What follows is the story that emerged from the nine pre-service teachers' experiences with assessment for learning in our methods courses during fall 2010:

At the beginning of the course, the pre-service teachers' writings were focused primarily on apprehensiveness about grades and optimism as well as apprehension about the opportunity for revision of work. In the middle of the course, the pre-service teachers' writings documented their continued frustration, nervousness and worry about grades. They also expressed happiness, with a few instances of frustration, about the support of their group and a mixture of confidence, trust and discomfort about the rubric $\&$ feedback. By the end of the course their writings revealed confidence and pride about: shifts in

Journal of the Scholarship of Teaching and Learning, Vol. 15, No. 3, June, 2015. 79 josotl.indiana.edu 
personal identity; shifts in beliefs about assessment and motivation; and notions of personal and professional growth.

Some of the powerful statements about shifts in identity, motivation, and agency recorded in pre-service teachers' journals at the end of the course can be found in Table 4.

\section{Table 4}

\section{Journal Entries from End of the Course Data Set}

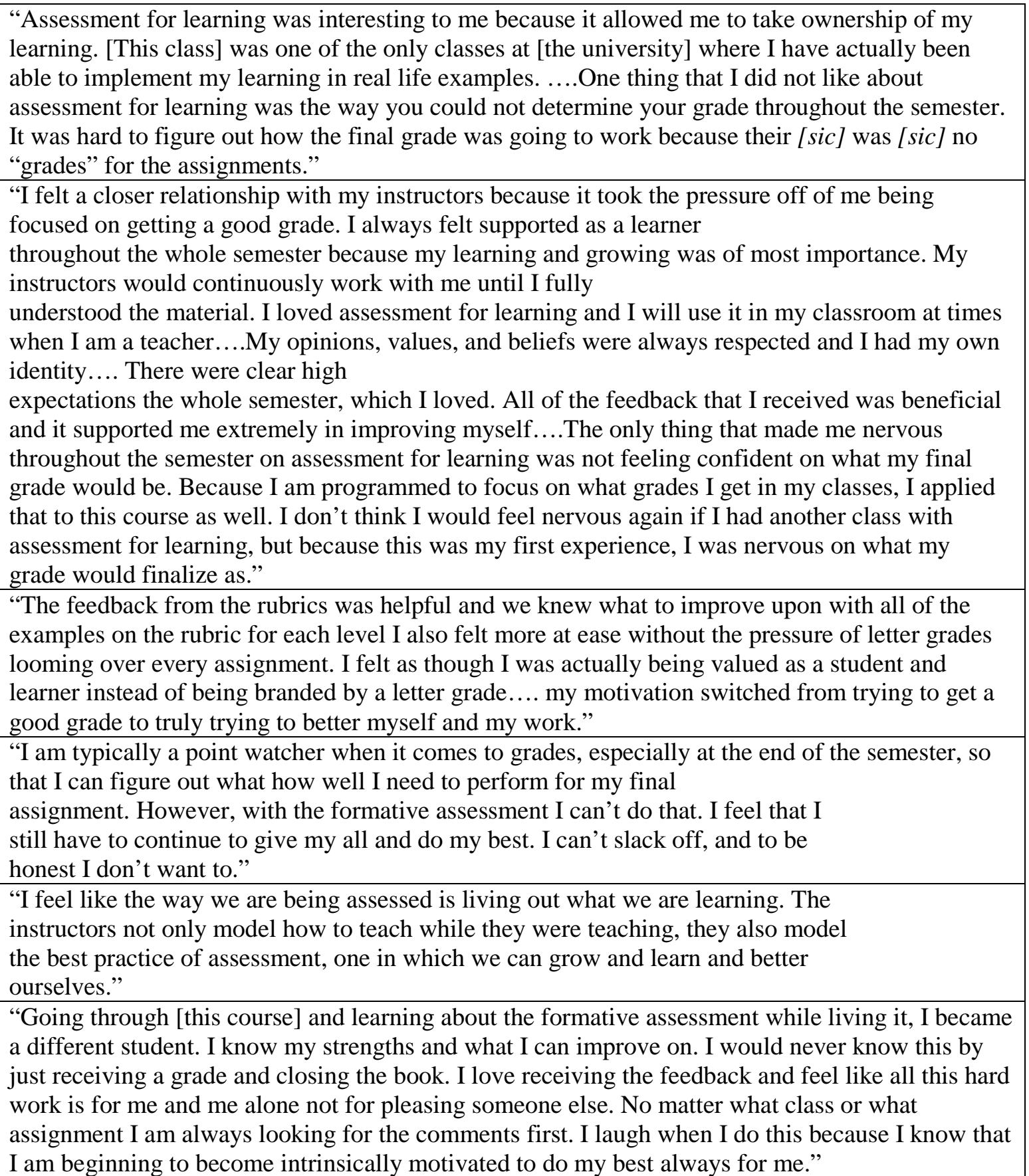

Journal of the Scholarship of Teaching and Learning, Vol. 15, No. 3, June, 2015. 80 josotl.indiana.edu 
These statements made us realize that our efforts to align our assessment practices with our values had definitely affected our pre-service teachers' sense of power, identity and agency in our class, in much the same manner as McClam and Sevier (2010) reported. They were intrinsically motivated to do their best and they were proud of their work and growth. Our results support Kohn's (1993) claim that building trust and striving for equity requires "bringing students into the evaluation process" (p. 209). Our results also align with the quantitative findings of McDowell, Wakelin, Montgomery and King (2011) in that our preservice teachers overwhelmingly preferred an assessment for learning environment.

Interestingly, pre-service teachers' evaluations of the course and the instructors also improved as a result of using assessment for learning practices. Again, this aligns with experiences reported in the literature. It is important to note, however, that the implementation of assessment for learning practices did not result in major changes in the way pre-service teachers' grades are distributed in our courses. The use of an assessment for learning framework did not mean that all pre-service teachers earned an A, nor did they come to the exit conferences claiming they had earned an A. In fact, in all but two of the fifty-eight exit conferences, the pre-service teachers' self-assessment of the grade they had earned was in agreement with our assessment of the grade they had earned. The use of formative assessment did not compromise the high expectations we had for our pre-service teachers; instead, it added supports for them to achieve those high expectations and to take ownership of their learning.

[curtain closes]

\section{Epilogue: What's in your syllabus?}

We started this course redesign and research project to improve our own assessment practices and that continues to be our goal. As a result of this study, we have arrived at three conclusions:

1. Assessment for learning was a positive course improvement for us because we were striving to live out our values and because our course evaluations drastically improved.

2. The vast majority (23 of the 29 who responded to the online survey) of our preservice teachers appreciated and preferred experiencing assessment for learning.

3. And most importantly, the use of assessment for learning enhanced the learning experiences, in terms of motivation, ownership, and pride in their work, of those pre-service teachers.

Any one of these outcomes would support the use of assessment for learning, but the combination is a particularly powerful result of this study.

In addition to our documented research results, we also attended to another detail as we implemented changes to our assessment practice. We conscientiously tried to avoid the pitfalls about which McClam and Sevier (2010) warned. We attempted to be transparent and communicate to others about the reform from the beginning. We did in fact inform our colleagues at a faculty retreat of our intentions to revise our course assessment. This announcement was met with vocal skepticism and questions. The concerns mostly Journal of the Scholarship of Teaching and Learning, Vol. 15, No. 3, June, 2015. 81 josotl.indiana.edu 
revolved around how we would help the students understand and transition to this form of assessment and how we would be able to justify the grade if and when a student appealed the grade. Despite these concerns, no one directly forbade us to move forward with our plan. Following our first semester of implementing the learning for assessment practices described in this article, we presented our very early research and initial results informally to our faculty at a 'brown bag' discussion, using a story-telling format called Readers Theatre. We included six of the nine (all were invited and six were able to attend) preservice teachers who participated in interview and journaling in that presentation to allow our faculty to hear both instructor and student voices. In this way, we sought feedback from other faculty members and we involved the pre-service teachers themselves in the reform movement. This 'brown bag' presentation was met with more positive than negative responses and it generated a great deal of interest in our assessment redesign work. We then presented this work at two National Assessment Institutes to share our findings and gather feedback from other university instructors. Currently, a few of our colleagues use assessment for learning in their courses; however, a substantial number remain grounded in traditional university assessment practices, including grading with points and percentages.

Since completing this study, we have continued to use assessment for learning in our pre-service methods courses. We have modified our competency-based rubric several times to better reflect expected learning outcomes. We have also instituted instructional conversations around each of the learning targets to help pre-service teachers better understand those learning goals. So far, none of the pre-service teachers in our courses have appealed the final grade they earned in the course. We are committed to an on-going review of our assessment practices and their impact on our pre-service teachers. We hope to inspire readers of this article to ask themselves this, "What's in my syllabus and how do my assessment practices affect my students?”

\section{Acknowledgement}

We wish to thank two of our former colleagues, Trish Weis and Carol Matern, for engaging in many of our original conversations regarding assessment for learning. Their thoughtful insights greatly informed this study and our actions around these assessment ideas.

\section{References}

Black, P., \& Wiliam, D. (2004). The formative purpose: Assessment must first promotelearning. In Wilson, M. (Ed.), Towards coherence between classroom assessment and accountability (pp. 20-50). Chicago, IL: University of Chicago Press.

Black, P., Harrison, C., Lee, C. Marshall, B., \& Wiliam, D. (2007). Assessment for learning: Putting it into practice. New York: Open University Press.

Boaler, J. (2009). What's math got to do with it? New York: Penguin Group. 
Bose, J., \& Rengel, Z. (2009). A model formative assessment strategy to promote student-centered self-regulated learning in higher education. Online Submission, ERIC, EBSCOhost

Butler, R. (1987) Task-involving and ego-involving properties of evaluation: Effects of different feedback conditions on motivational perceptions, interest and performance, Journal of Educational Psychology, 78(4), 210-216.

Council for the Accreditation of Educator Preparation (2013). Accreditation standards. Retrieved from http://www.caepsite.org/standards.html

Hattie, J., \& Timperley, H. (2007). The power of feedback. Review of Educational Research, 77(1), 81-112.

Jones, S. R. (2002). Becoming grounded in grounded theory methodology. In S. B. Merriam and Associates (Eds.), Qualitative research in practice: Examples for discussion and analysis (pp. 175-177). San Francisco: Jossey-Bass.

Kohn, A. (1993). Punished by rewards: The trouble with gold stars, incentive plans, A's, praise, and other bribes. Boston: Houghton Mifflin Company.

Ladson-Billings, G. (2009). The dreamkeepers: Successful teachers of African American children. San Francisco: John Wiley \& Sons.

McClam, S., \& Sevier, B. (2010). Troubles with grades, grading, and change: Learning from adventures in alternative assessment practices in teacher education. Teaching and Teacher Education, 26(7), 1460-1470.

McDowell, L.,Wakelin, D.,Montgomery, C., \& King, S. (2011). Does assessment for learning make a difference? The development of a questionnaire to explore the student response. Assessment \& Evaluation in Higher Education, 36(7), 749-765.

National Council of Teachers of English (2013). Position statement: Formative assessment that truly informs instruction. Retrieved from http://www.ncte.org/positions/statements/formative-assessment

National Council of Teachers of Mathematics (2013). Position Statement on Formative Assessment. Retrieved from www.nctm.org/formative

Nicol, J. D. \& Macfarlane- Dick, D., (2006). Formative assessment and self-regulated learning: A model and seven principles of good feedback practice, Studies in Higher Education, 31(2), 199-218.

Pintrich, P. R. (1995) Understanding self-regulated learning. San Francisco, CA: JosseyBass.

Journal of the Scholarship of Teaching and Learning, Vol. 15, No. 3, June, 2015. 83 josotl.indiana.edu 
Pintrich, P. R., \& Zusho, A. (2002) Student motivation and self-regulated learning in the college classroom. In J. C. Smart \& W.G. Tierney (Eds.), Higher education: handbook of theory and research (vol. XVII). New York: Agathon Press.

Stiggins, R. J. (2002). Assessment crisis: The absence of assessment for learning. Phi Delta Kappan, 83(10), 758-765.

Strauss, A., \& Corbin, J. (1990). Basics of qualitative research: Grounded theory procedures and techniques. Newbury Park, CA: Sage Publications, Inc.

Wiggins, G. (2012). 7 keys to effective feedback. Educational Leadership, 70(1), 11-16.

Wiliam, D. (2007). Research Brief: Five key strategies for effective formative assessment. Reston, VA: National Council of Teachers of Mathematics. Zimmerman, B. J., \& Schunk, D. H. (2001) Self-regulated learning and academic achievement: theoretical perspectives. Mahwah, NJ: Lawrence Erlbaum Associates.

Zimmerman, B. J., \& Schunk, D. H. (2004) Self-regulating intellectual processes and outcomes: A social cognitive perspective. In D. Y. Dai \& R. J. Sternberg (Eds.), Motivation, emotion and cognition. Mahwah, NJ: Lawrence Erlbaum Associates. 